\title{
Condiciones para un buen estudio de susceptibilidad mediante test de difusión en agar
}

\author{
ERNA CONA T.*

\begin{abstract}
REQUIREMENTS FOR THE ADEQUATE PERFORMANCE OF AGAR SUSCEPTIBILITY TEST
\end{abstract}

The in vitro susceptibility testing of an antibiotic against pathogenic microorganisms can be performed by different methods being the agar disk diffusion the most commonly used by the microbiology laboratories, which hes been standardized for fast growing and some fastidious bacteria. The standardized method, which is recommended by NCCLS, is based on the one described originally by Bauer et al, whose qualitative results are well correlated to the quantitative ones obtained by (MIC) minimal inhibitory concentration.

Key words: Agar diffusion, Antimicrobial agents, Disk diffusion, Kirby Bauer method, Susceptibility testing.

\section{INTRODUCCIÓN}

Una variedad de métodos pueden ser utilizados para medir la susceptibilidad in vitro de los microorganismos patógenos a antimicrobianos, el de uso más común en los laboratorios de microbiología es la difusión en agar estandarizado para microorganismos de crecimiento rápido y algunos de crecimiento fastidioso.

Para un resultado confiable con este test se debe trabajar con una metodología estandarizada y la medición del halo de inhibición debe correlacionarse con la CIM de cepas con susceptibilidad o resistencia conocida a varios antimicrobianos.

El método estandarizado comúnmente reco- mendado por el NCCLS se basa en el originalmente descrito por Bauer et al. ${ }^{1}$

\section{Indicaciones para un estudio de susceptibilidad in vitro}

- Cualquier microorganismo que requiera terapia, cuya susceptibilidad sea impredecible.

- Microorganismos con susceptibilidad predecible en pacientes con antecedente de hipersensibilidad a fármacos.

- Especie aislada potencialmente resistente a los antimicrobianos de uso común.

- Estudios epidemiológicos de resistencia.

- Evaluación de nuevos agentes antimicrobianos.

\footnotetext{
* Laboratorio de Microbiología, Hospital Clínico General Dr. Raúl Yazigi J., Clínica Indisa.
} 


\section{Condiciones para un estudio de susceptibilidad}

- Trabaje con colonias aisladas.

- No realice en forma directa de material clínico.

- No efectúe estudio a la flora microbiana residente o a microorganismos improbablemente relacionados con el proceso infeccioso

\section{Selección de los antimicrobianos}

La selección de los antimicrobianos a utilizar es una decisión conjunta del laboratorio de microbiología, equipo de infectología, comité de infecciones intrahospitalarias y farmacia.

\section{Características de los antimicrobianos} a ensayar

- Deben ser fármacos aprobados por la FDA.

- De eficacia clínica demostrada para el microorganismo en estudio.

- Factibles de evaluar in vitro.

- Útiles como marcadores en IIH o con propósitos epidemiológicos.

\section{Informe de los antibiogramas}

- Debe contener un número limitado de antimicrobianos.

- Incluya sólo fármacos apropiados para la localización de la infección a tratar.

- En el informe utilice los nombres farmacéuticos (evite nombres comerciales).

\section{El medio base recomendado para} realizar un antibiograma por difusión es el agar Mueller Hinton por:

- Su reproducibilidad aceptable.

- Baja concentración de inhibidores, condición crítica para evaluar sulfonamidas, trimetoprim y tetraciclina.

- El crecimiento satisfactorio de patógenos no fastidiosos.

- Existir ya gran experiencia en estudios de susceptibilidad.

Nota: Es utilizable sólo para bacterias (aerobias o facultativas) no fastidiosas.

\section{Preparación del agar Mueller Hinton}

- Agar base deshidratado.

- Post autoclavado enfríe en baño a $45-50^{\circ} \mathrm{C}$.

- Vierta a placa en superficie horizontal $4 \mathrm{~mm}$ de profundidad.

- Volumen: 60-70 $\mathrm{ml}$ para placas de $150 \mathrm{~mm}$ y 25-30 ml para placas de $100 \mathrm{~mm}$.

- Enfríe a $\mathrm{T}^{\circ}$ ambiente, almacene en refrigeración $\left(4-8^{\circ} \mathrm{C}\right)$.

- Duración: 7 y hasta 14 días (en manga de polietileno).

- Realice control de esterilidad y calidad.

Efectos del pH sobre el agar Mueller

Hinton: (el rango de $\mathrm{pH}$ va de 7,2 a 7,4)

- A pH ácido:

- Pierden potencia los aminoglucósidos y macrólidos.

- Aumenta la actividad de penicilinas.

- A pH alcalino: los efectos son opuestos.

- Controle el pH post gelificación.

Efectos de la timidina o timina sobre el agar Mueller Hinton:

- Medios con exceso de timidina dan falsa resistencia a sulfonamidas y trimetoprim.

- Evalúe cada lote nuevo de agar Mueller Hinton con Enterococcus faecalis ATCC 29212, o ATCC 33186 y, con cotrimoxazol (SXT).

- Un halo de inhibición para SXT > 20 mm es satisfactorio.

- Un halo de inhibición < 20 mm o crecimiento intra-halo es insatisfactorio.

\section{Influencia de las variación de cationes divalentes sobre el agar Mueller Hinton:}

- La variación de $\mathrm{Ca}^{++}$y $\mathrm{Mg}^{++}$afecta los halos de inhibición para aminoglucósidos y tetraciclinas en Pseudomonas aeruginosa.

- El contenido excesivo de cationes produce halos de falsa resistencia.

- El contenido bajo de cationes produce falsa susceptibilidad.

- El ión $\mathrm{Zn}^{++}$afecta la determinación de susceptibilidad a carbapenems. 
Influencia de la profundidad del agar Mueller Hinton:

- La profundidad recomendada de la capa de agar es de 3 a $5 \mathrm{~mm}$.

- Una profundidad $<3 \mathrm{~mm}$ genera lecturas falsamente susceptibles.

- Una profundidad > $5 \mathrm{~mm}$ genera lecturas falsamente resistentes.

\section{Conservación de los sensidiscos}

- Refrigere a $8^{\circ} \mathrm{C}$ o congele a $-14^{\circ} \mathrm{C}$ o menos.

- $\beta$ lactámicos: manténgalos congelados, sólo refrigere lo que está en uso (máximo 7 días).

- Antimicrobianos lábiles (imipenem, combinaciones con clavulanato) son más estables si se mantienen siempre congelados.

- La superficie del agar debe estar húmeda pero sin gotas de agua visible.

- Retire del refrigerador 1 a 2 horas antes de utilizarlo(s).

- Los envases deben tener desecantes.

- La fecha de expiración debe estar vigente.

\section{Estándar de turbidez} (etalón Mc Farland)

- Un Mc Farland 0,5 corresponde a un desarrollo de $1,5 \times 10^{8} \mathrm{UFC} / \mathrm{ml}$

-verifique la densidad correcta del etalón en forma mensual. (absorbancia a $625 \mathrm{~nm}=$ 0,08 a 0,10 )

-la turbidez del etalón debe ser uniforme post agitación con vórtex.

-Almacene en la oscuridad.

\section{Antibiograma por técnica de difusión: Procedimientos}

\section{Preparación del inóculo}

Método de crecimiento activo recomendado para microorganismos no fastidiosos

- Tome 3 a 5 colonias de igual morfología y emulsione en 4 a $5 \mathrm{ml}$ de caldo tripticasa soya.
- Incube a $35{ }^{\circ} \mathrm{C}(2-6 \mathrm{hrs})$. (Ajuste la turbidez con solución salina $(\mathrm{NaCl}$ $9 \%$ o) estéril a McF 0,5 con luz adecuada, contra tarjeta blanca con una línea negra de contraste).

Método de suspensión directa de colonia (recomendado para microorganismos de crecimiento fastidioso como Streptococcus spp, Haemophilus spp, Neisseria gonorrhoeae, Staphylococcus spp)

- Prepare inóculo con ajuste de turbidez McFarland 0,5, directo en caldo de colonias frescas en agar no selectivo.

\section{Inoculación de placas}

- Dentro de 15 min de hecho el ajuste de la turbidez.

- Con tórula en tres direcciones inocule toda la placa (giros de $60^{\circ}$ ).

- Deje impregnar durante no más de 15 min. Nota:

- No utilice caldos de $18 \mathrm{hrs}$.

- No utilice inóculos no estandarizados.

\section{Aplicación de sensidiscos}

- Cantidad: 12 unidades en placas de $150 \mathrm{~mm}$ y 5 unidades en placas de $100 \mathrm{~mm}$.

- Separación: $24 \mathrm{~mm}$ (del centro de un sensidisco al otro más cercano).

- La difusión del fármaco es instantánea: no reubique los sensidiscos después de haberlos depositado en la superficie del agar.

- Incube en $\mathrm{O}_{2}$ a $35^{\circ} \mathrm{C}$ (excepto Haemophilus $s p$, N. gonorrhoeae y Streptococcus pneumoniae).

\section{Lectura e interpretación de halos de inhibición (Figura 1)}

- Uso de luz reflejada con fondo oscuro:

- mida el crecimiento confluente.

- SXT puede producir un doble halo

- en Proteus spp. ignore la invasión.

- ignore colonias pequeñas intra-halo excepto en Staphylococcus y Enterococcus spp. 


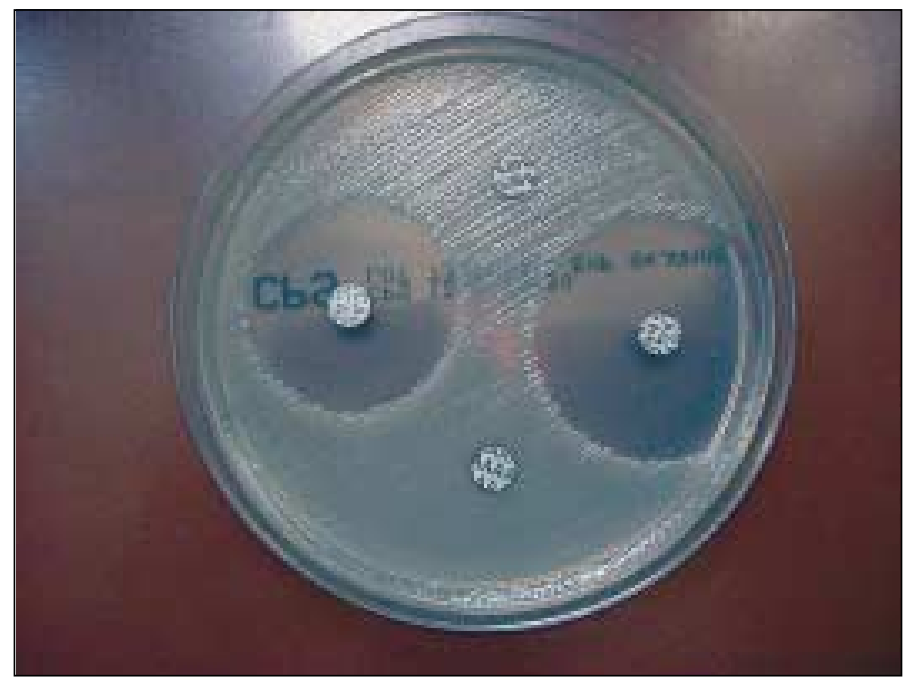

Figura 1. Antibiograma de Escherichia coli efectuado por método de Kirby-Bauer. Se aprecia $\mathrm{R}$ a ampicilina y cefadroxilo, $\mathrm{S}$ a cefotaxima e imipenem. (Gentileza de P. García).

- Uso de luz transmitida:

- En Staphylococcus spp frente a oxacilina.

- En Enterococcus spp frente a vancomicina.

- Incube durante 16 a 18 hrs.

- Staphylococcus spp y Enterococcus spp, incube durante $24 \mathrm{hrs}$.

- El margen es la zona que no muestra evidencia ocular de cultivo visible.
- Ignore las colonias diminutas con lupa en el margen.

- Subcultive las colonias existentes dentro de las zonas de inhibición neta.

- En medios suplementados con sangre se debe medir la inhibición de crecimiento, no la hemólisis.

- Para la interpretación de los halos de inhibición medidos utilice las tablas NCCLS vigentes. $^{2}$

Listado de cepas ATCC empleadas en el control calidad

\begin{tabular}{ll}
\hline \multicolumn{1}{c}{ Cepa } & \multicolumn{1}{c}{ Uso } \\
\hline Escherichia coli 25922 & - antimicrobianos para Gram(-)s \\
Escherichia coli 35218 & - antimicrobianos con inhibidor de b lactamasas \\
Staphylococcus aureus 25923 & - antimicrobianos para Gram(+)s \\
Staphylococcus aureus 38591 & - screening de oxacilina \\
Pseudomonas aeruginosa 27853 & - antimicrobiano para Gram(-)s \\
Enterococcus faecalis 29212 & - aceptabilidad para SXT \\
Streptococcus pneumoniae 49619 & - Mueller Hinton con sangre \\
Haemophilus influenzae 49247 & - medio HTM \\
Neisseria gonorrhoeae 49226 & - agar GC \\
\hline
\end{tabular}


Estudio de susceptibilidad mediante test de difusión en agar - E. Cona T.

TABLA RESUMEN

Variables a controlar en la ejecución del antibiograma por difusión:

- inóculo

- medio de cultivo $*$ formulación

* contenido de $\mathrm{Ca}^{++} \mathrm{y} \mathrm{Mg}^{++}$.

* contenido de timidina

* ph

* profundidad del agar

- sensidiscos:

* concentración (carga)

* mantención

* número apropiado

- incubación: * atmósfera

* temperatura

* tiempo de incubación

- lectura e interpretación de halos de inhibición.

\section{Controles de calidad: Propósitos}

\section{Monitorizar:}

- La precisión del procedimiento.

- Los reactivos utilizados.

- Al personal que realiza el procedimiento y lectura.

Utilice cepas ATCC de referencia (garantizan su estabilidad genética)

\section{RESUMEN}

El estudio de susceptibilidad in vitro a antimicrobianos de los microorganismos patógenos, puede realizarse a través de diversos métodos, el de uso más común por los laboratorios de microbiología es el de difusión en agar, estandarizado para microorganismos de crecimiento rápido y algunos fastidiosos. El método estandarizado y recomendado por el NCCLS se basa en el descrito originalmente por Bauer et al, que obtiene resultados cualitativos que correlacionan bien con los resultados cuantitativos obtenidos mediante determinación de CIM (concentración inhibitoria mínima).

\section{BIBLIOGRAFÍA}

1.- BAUER A W, KIRBY W M, SHERRIS J C, TURCK M. Antibiotic susceptibility testing by standardized single disk method. Am J Clin Pathol 1966; 45: 493-6.

2.- National Committee for Clinical Laboratory Standards. Performance standards for antimicrobial susceptibility testing. XII Informational Supplement. M100-S12. Wayne, Pennsylvania, NCCLS, 2002.

3.- National Committee for Clinical Laboratory Standards (NCCLS). Disk diffusion supplemental tables M100S10 (M2), January 2001.

4.- CHAPTER 111. Susceptibility test: Diffusion test procedures. In Ballows A, Hausler Jr W J, Kenneth L H, Isemberg H D. Manual of Clinical Microbiology, 1991, fitth ed, pp: 1117-25.

5.- CHAPTER 112. Antimicrobial susceptibility test: Fastidious and unusual bacteria. In Ballows A, Hausler Jr WJ, Kenneth L H, Isemberg H D. Manual of Clinical Microbiology, 1991, fifth ed, pp 1126-32.

6.-BAKER C N, HAWKINSON R W. Inoculum standardization in antimicrobial susceptibility test: Evaluation of the use of overnight agar cultures and the rapid inoculum standardization system. J Clin Microbiol 1983; 17: 450-7.

Correspondencia a:

Erna Cona Trujillo

E-mail: econa@ctcinternet.cl 